\title{
An analysis of phenomena accompanying ring collaboration with worn cylinder surface
}

\author{
The presented study which refers to the earlier papers of the authors discusses an effect of cylinder wall deformation \\ on the effectiveness of compression ring operation. Presented models permit a mathematical description of a deformed \\ cylinder and definition of ring wall pressure relative to these deformations. \\ The drafts presented in the paper, obtained in a course of calculations of a compression ring installed in a work ma- \\ chine engine, allow to evaluate the effect of cylinder deformations on distribution of ring circumferential pressure and \\ point out areas where the light slots could occur.
}

Key words: piston ring, oil film, ring wall pressure

\section{Analiza zjawisk towarzyszących współpracy pierścienia tłokowego ze zużytą powierzchnią gładzi cylindra}

\begin{abstract}
W niniejszej pracy, wiążacej się tematycznie z wcześniejszymi publikacjami autorów, określono wptyw zmian kształtu otworu cylindra na skuteczność pracy pierścienia uszczelniającego. Zaprezentowano modele, umożliwiające matematyczny opis odksztatconego otworu cylindra, a także wyznaczenie odpowiadającego tym odkształceniom nacisku pierścienia na gładź cylindra.

Na zamieszczonych w opracowaniu wykresach, uzyskanych podczas obliczeń pierścienia uszczelniającego pracujacego w silniku spalinowym maszyny roboczej, pokazano przebiegi pozwalające ocenić wpływu wartości zniekształcenia otworu cylindra na rozkład nacisków obwodowych, a także wskazano miejsca, w których możliwe jest pojawienie się tzw. szczelin świetlnych.
\end{abstract}

Słowa kluczowe: pierścień tłokowy, film olejowy, rozkład nacisków pierścienia

\section{Introduction}

Piston together with rings and cylinder liner form a mobile labyrinth sealing. Its basic goal is a tight combustion chamber. It is assumed at the stage of ring design that it will move along a cylinder of circular cross-section. Test revealed that any deviation of this shape lead to a drop in tightness efficiency, increased wear of collaborating ring and liner as well as such unfavorable effects as oil film ruptures and gas blow-by.

Within an entire cycle of engine operation the compression ring wall pressure resulting from its own elasticity and external forces should be high enough to extort mutual contact of their faces. Within the external forces the most important one is a gas force varying during the engine operation cycle. Calculations show that the momentary ring pressure resulting from this force could exceed several times the pressure of ring own elasticity.

Basic data characteristic for ring design are calculated assuming circular circumference. However, measurements show that even new liners reveal considerable deviation from this assumption. In order to limit the effect of liner deformation on proper operation of the sealing the limits of orifice shape error (its roundness, rectilinearity and coaxiality) should be defined. For example, for the HDD engines the tolerance limit of shape error should lie within limits of 6-10 $\mu \mathrm{m}$ [1].

The errors of macroshape could occur also at the stage of engine assembly; for instance, exemplary cylinder defor-

\section{Wprowadzenie}

Tłok oraz osadzone na nim pierścienie tworzą wraz z tuleją cylindrową ruchome uszczelnienie labiryntowe, którego podstawowym zadaniem jest zapewnienie szczelności komorze spalania. Podczas projektowania pierścienia uszczelniającego zakłada się, że będzie się on przemieszczał w cylindrze o przekroju kołowym. Badania wykazują, że wszelkie odstępstwa od tego kształtu powodują spadek skuteczności uszczelnienia, zwiększone zużycie współpracujących powierzchni pierścienia i cylindra, a także pojawienie się takich niekorzystnych zjawisk, jak zaniki ciągłości filmu olejowego i przedmuchy gazów.

W całym cyklu pracy silnika nacisk pierścienia uszczelniającego na gładź cylindra, wywołany sprężystością własną pierścienia oraz działaniem sił zewnętrznych, powinien być na tyle duży, aby wymuszał wzajemne przyleganie ich powierzchni roboczych. W grupie sił zewnętrznych do najważniejszych zalicza się siłę gazową, której wartość zmienia się i zależności od fazy cyklu pracy silnika. Obliczenia wykazują, że powstający w wyniku działania tej siły chwilowy nacisk pierścienia może wielokrotnie przewyższyć docisk wynikający z jego sprężystości własnej.

Podstawowe wielkości charakteryzujące konstrukcję pierścienia tłokowego są obliczane przy założeniu, że jego linia obwodowa jest okręgiem. Tymczasem pomiary nawet nowych tulei cylindrowych wykazują znaczne odstępstwa od tego założenia. W celu ograniczenia wpływu zniekształceń 
mations caused by installation of cylinder head are shown in [2].

Mechanical and thermal loads caused by phenomena accompanying engine operation affect to high degree the geometry of cylinder liner. As a result of their working a momentary or permanent change in liner shape occurs and its size depends above all on the value and location of load, applied material, the way liner is installed in cylinder block, type of cooling and so on. There are estimations that the size of deformations caused by such loads can reach the value within the range of 30-60 $\mu \mathrm{m}$.

Fig. 1 shows several cases of cylinder deformations corresponding to the model loads.

In a case when deformation does not exceed the yield point of liner material restitution is possible after load disappearance. This does not happen when permanent deformations occur because of wear. Fig. 2 presents a typical course of worn cylinder generatrix. The greatest change in bore radius $\Delta \mathrm{r}$ occurs most often at the upper part of cylinder where the first compression ring contacts with the bore.

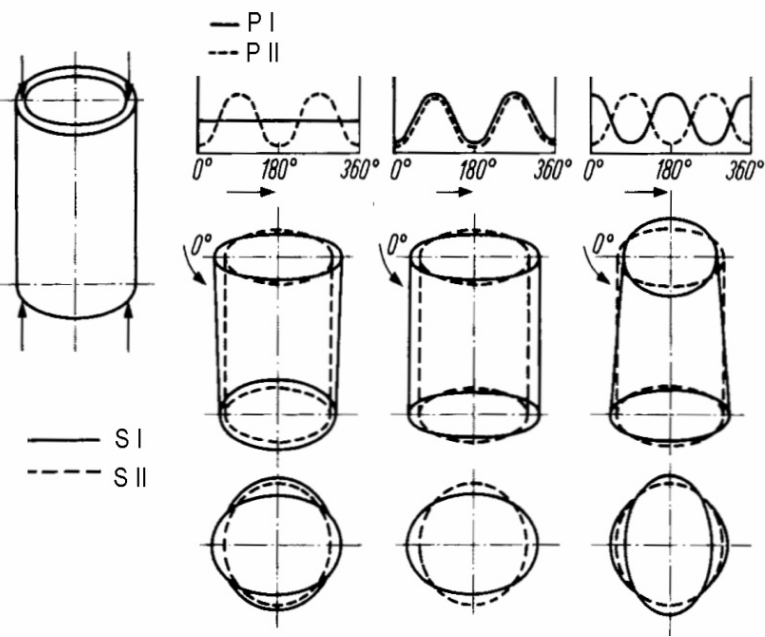

Fig. 1. Deformations of cylinder sinusoidaly loaded along its circumference; PI i PII - load on upper and lower part of cylinder, respectively, SI i SII - shape of cylinder bore before and after load, respectively [3]

Rys. 1. Odkształcenia cylindra obciążonego sinusoidalnie na obwodzie; PI i PII-obciążenie, odpowiednio górnej i dolnej części cylindra, SI i SII - ksztalty otworu cylindra, odpowiednio przed i po obciążeniu [3]

Beside the characteristic changes observed along the cylinder generatrix the variations of its circumferential line occur as well. These variations are the individual ones and concern a single cylinder. They are caused by natural wear or by the problems due to the engine run. It is generally considered that the following reasons affect the wear of cylinder bore to the highest extend:

- type of lubricating system and use of various lubricating oils,

- different operational conditions of some details of pistoncylinder system due to various errors encountered at the stage of engine assembly and adjustment,

- different conditions of single cylinder operation, e.g. common turbocharger, na poprawność pracy uszczelnienia określa się graniczne wartości błędów makrokształtu otworu (jego okrągłości oraz prostoliniowości lub współosiowość). Przykładowo, dla silników HDD graniczna wartość tolerancji błędu kształtu powinna mieścić się $\mathrm{w}$ granicach 6-10 $\mu \mathrm{m}$ [1].

Błędy makrokształtu otworu mogą także powstawać w fazie montażu silnika; przykładowe odkształcenia cylindra powstające podczas łączenia głowicy z blokiem cylindrowym pokazano m.in. w pracy [2].

$\mathrm{Na}$ geometrię cylindra (tulei cylindrowej) w sposób bardzo istotny wpływają obciążenia mechaniczne i cieplne, wywołane zjawiskami towarzyszącymi pracy silnika. W efekcie ich działania następuje chwilowa lub trwała zmiana kształtu otworu tulei, a jej wielkość zależy przede wszystkim od wartości oraz miejsca działania obciążenia, zastosowanego materiału, sposobu mocowania tulei w kadłubie, rodzaju jej chłodzenia itp. Ocenia się, że wielkość odkształceń wywołanych tymi obciążeniami może osiągać wartości mieszczące się w granicach 30-60 $\mu \mathrm{m}$.

Na rysunku 1 pokazano kilka przykładowych przypadków odkształcenia cylindra odpowiadających zamodelowanemu obciążeniu.

W przypadkach, gdy wielkość odkształcenia nie przekroczy jeszcze granicy sprężystości materiału tulei, po zaniku obciążenia możliwy jest powrót do kształtu początkowego. Nie nastąpi to jednak w sytuacji, gdy w wyniku zużycia dojdzie do trwałych zmian kształtu otworu. Na rysunku 2 pokazano typowy przebieg tworzącej zużytego cylindra. Największa zmiana promienia otworu $\Delta \mathrm{r}$ pojawia się najczęściej w górnej jego części, w obszarze styku pierwszego pierścienia uszczelniającego z gładzią cylindra.

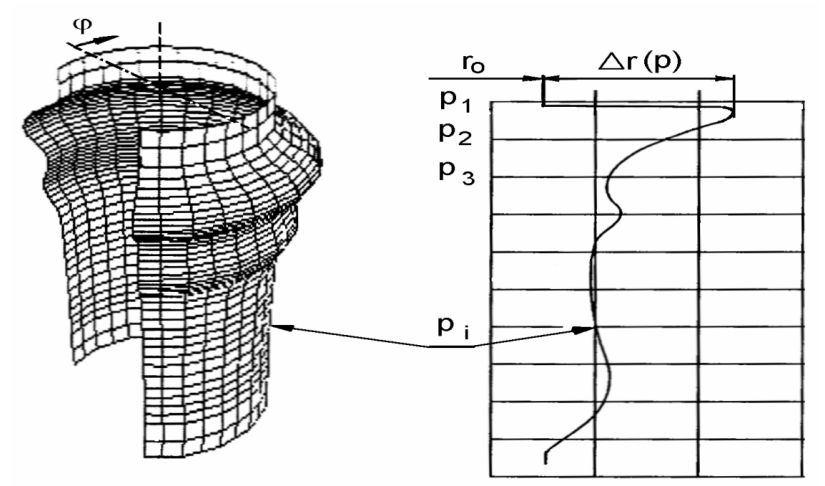

Fig. 2. Example of cylinder bore generatrix course; $p_{i}-$ plane of cylinder cross-section

Rys. 2. Przykładowy przebieg tworzacej cylindra silnika spalinowego, $p_{i}$ - płaszczyzna przekroju cylindra

Poza charakterystycznym zmianami obserwowanym wzdłuż tworzącej cylindra pojawiają się również zmiany przebiegu jego linii obwodowej. Zmiany mają najczęściej charakter indywidualny dla danego cylindra i są wywołane jego naturalnym zużyciem, a także mogą być spowodowane problemami towarzyszącymi eksploatacji silnika. Uważa się, że największy wpływ na zużycie gładzi cylindra mają (podane dalej przyczyny dotyczą przede wszystkim silnika okrętowego [4]): 
- constructional, material, technological and assembly conditions of individual cylinders.

All deformations of cylinder bore influence negatively on quality of sealing operation. The authors wrote about this previously when analyzing the effect of uniformly worn cylinder bore on correctness of compression ring operation [6]. Phenomena encountered during engine run lead to the bore uneven wear and cylinder cross-section far from the circular one. Because of that the definition of change in cylinder circumferential line effect on operation of compression ring, circumferential distribution of ring wall pressure in particular was chosen as the goal of presented paper.

\section{Modeling of collaboration of compression ring with a deformed cylinder bore}

In [5] authors presented the method how to determine the distribution of ring elastic pressure against the circular cylinder bore. The investigations concerned a bore in which the diameter nominal at the beginning rose gradually along with the wear. For computations the real ring was replaced by a computational model composed of a number of rigid rectilinear sections connected with joints one to another. The mathematical description of forces and moments acting in joints together with knowledge on ring geometry allowed to determine a circumferential distribution or ring wall pressure.

Presented in [5] results of model investigations were carried out for the compression ring of marine engine of constant wall pressure at the beginning. The

a)

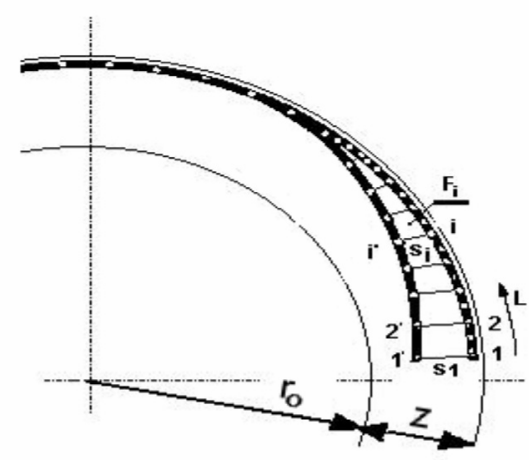

b)

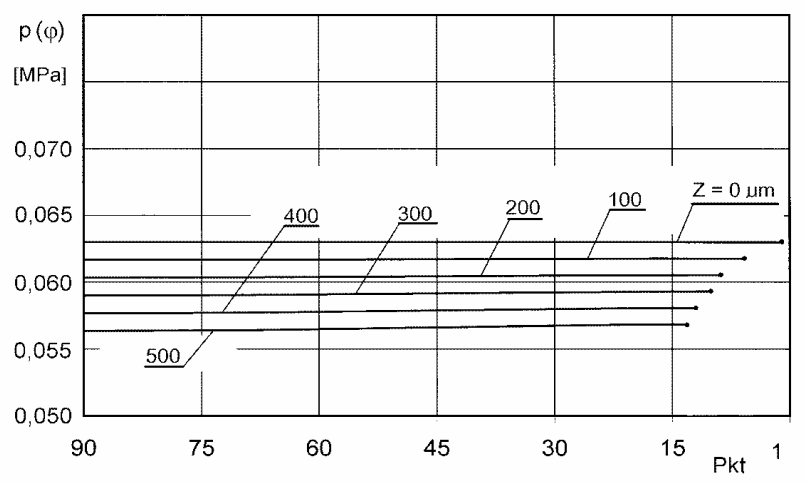

- konstrukcję układu smarowania i stosowanie różnych gatunków olejów smarowych,

- odmienne warunki pracy niektórych elementów układu tłokowo-cylindrowego spowodowane różnego rodzaju błędami powstającymi podczas montażu i regulacji silnika,

- odmienne warunki współpracy dla pewnej grupy cylindrów (np. wspólna turbosprężarka),

- indywidualne różnice konstrukcyjne, materiałowe, technologiczne i montażowe poszczególnych cylindrów.

Wszelkie odkształcenia otworu cylindra mają bardzo negatywny wpływ na jakość pracy uszczelnienia. Autorzy pisali już wcześniej o tym problemie analizując wpływ równomiernego zużycia powierzchni cylindra na poprawność pracy pierścienia uszczelniającego [6]. Zjawiska, działające podczas eksploatacji silnika powodują, że zużycie gładzi nie jest równomierne, a przekrój otworu cylindra znacznie odbiega od okręgu. Dlatego za cel tego opracowania przyjęto określenie wpływu zmian przebiegu linii obwodowej cylindra na pracę pierścienia uszczelniającego, w szczególności na obwodowy rozkład jego nacisku na gładź cylindra.

\section{Modelowanie wspólpracy pierścienia uszczelniającego z odkształconą gładzią cylindra}

Metodę wyznaczenia rozkładu nacisku sprężystego pierścienia na ścianki okrągłego cylindra przedstawili autorzy w pracy [5]. Badania dotyczyły cylindra, w którym średnica, początkowo nominalna, równomiernie wzrastała wraz $\mathrm{z}$ jego zużyciem. Podczas obliczeń pierścień rzeczywisty zastąpiono modelem obliczeniowym, złożonym z dużej liczby sztywnych odcinków prostoliniowych połączonych przegubami. Opis matematyczny sił i momentów działających w przegubach, przy jednoczesnej znajomości geometrii pierścienia, pozwalał wyznaczać obwodowy rozkład jego nacisku na gładź cylindra.

Wyniki badań modelowych, przedstawione w pracy [5], zostały wykonane dla pierścienia uszczelniającego

c)

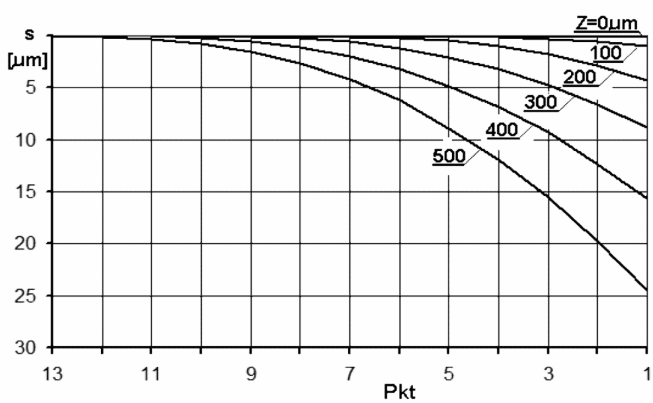

Fig. 3. The shape adopted by ring (a), changes in its circumferential wall pressure $p(\varphi)(b)$ and light slot wideness s (c) caused by the increase in bore wear; Pkt - points on bore surface counted starting from ring free gap [5]

Rys. 3. Kształt przyjmowany przez pierścień (a), zmiany jego nacisku obwodowego $p(\varphi)(b)$ oraz szerokość szczeliny $s(c)$ wywolane wzrostem zużycia z gładzi cylindra; Pkt-punkty na powierzchni cylindra liczone od zamka pierścienia [5] 
achieved results confirmed the assumption that the ring touches the wall with its entire circumference only in the new bore (for which the wear $\mathrm{z}_{\mathrm{a}}=0 \mu \mathrm{m}-$ Fig. 3). Along with the increase in wear the ring pressure decreases (see Fig. 3b) and the length of its contact with bore decreases at the same time (Fig. 3c). This effect could be explained by the increasing distance of ring ends from the bore (as shown in Fig. 3a).

The phenomenon of pressure drop in gap vicinity due to wear of bore is well known to designers of piston rings. To prevent the negative effect of this (blow-by, first of all) the increased elastic pressure of ring is anticipated in this area at the design stage.

The calculational method proposed in [2] allows for a precise determination of ring pressure circumferential distribution against the new or evenly worn bore. In the case of bore non-circular deformation a calculational problem emerges, i.e. there are considerable fluctuations in pressure which are not physically justified. The study [2] proposes a method that allows elimination or limitation of this phenomenon. The authors of this study decided that to achieve the appointed goal the analytical methods should be use, though less accurate and applicable in a limited range can obtain stable results for bore deformations presented in this paper.

\section{Mathematical illustration of bore circumferential line}

Construction of cylinder bore 3D picture requires a knowledge of its circumferential lines course (at selected planes) and generatrices of profile. For a selected plane the changes in cylinder radius $\Delta r(\varphi)$, caused by the change in bore shape can be expressed as a difference between an actual and initial radius, or as a sum of components $\mathrm{z}_{\mathrm{a}}$ and $\mathrm{z}_{\mathrm{b}}(\varphi)$ (see Fig. 4).

$$
\Delta r(\varphi)=z_{a}+z_{b}(\varphi)
$$

where the $z_{a}$ component is a mean value of radius increase while the $z_{b}(\varphi)$ component is a deviation from the mean line measured along the cylinder circumference. When there is no bore deformation, i.e. $z_{b}(\varphi)=0$, the component $z_{a}$ means the wear of cylinder bore.

For mathematical description of bore form the Fourier series can be applied

$$
\mathrm{z}_{\mathrm{b}}(\varphi)=\sum_{\mathrm{h}=1}^{\mathrm{n}} \mathrm{A}_{\mathrm{h}} \cos \left(\mathrm{h} \varphi+\delta_{\mathrm{h}}\right)
$$

where factors $A_{h}$ and $\delta_{h}$ are amplitude and phase shift of consecutive harmonics in series.

Due to change in shape of bore the wall pressure of ring inside undergoes the change from initial constant $\left(p(f)=p_{z}=\right.$ const) to a variable along the bore circumference. Execution of circumferential line course description and the neutral line of free ring is necessary to calculate this pressure.

After ring installation in the bore the curvature of its neutral plane changes itself from the one corresponding to silnika okrętowego, o początkowo stałym nacisku obwodowym. Uzyskane wyniki potwierdziły przypuszczenie, że tylko w nowym cylindrze (dla którego zużycie $\mathrm{z}_{\mathrm{a}}=0 \mu \mathrm{m}-$ rys. 3) pierścień całym obwodem przylega do gładzi cylindra. Wraz ze wzrostem zużycia nacisk pierścienia zmniejsza się (rys. 3b), a jednocześnie maleje długość linii jego kontaktu z gładzią (rys. 3c). Efekt ten jest spowodowany oddalaniem się końców pierścienia od powierzchni cylindra (co pokazano na szkicu na rys. 3a).

Zjawisko spadku nacisku w obszarze zamka, spowodowane zużyciem gładzi, znane jest konstruktorom pierścieni tłokowych. W celu zapobieżenia jego negatywnym skutkom (w tym przede wszystkim przedmuchom gazów) już w fazie konstruowania w tym właśnie obszarze nadaje się pierścieniowi zwiększony nacisk własny.

Proponowana w pracy [2] metoda obliczeniowa pozwala precyzyjnie wyznaczyć rozkład obwodowego nacisku pierścienia na nową względnie równomiernie zużytą gładź cylindra. W przypadków niekołowego odkształcenia cylindra pojawia się jednak problem obliczeniowy, objawiający się znacznymi fluktuacjami wartości nacisku, co nie ma jednak fizycznego uzasadnienia. Metodę, pozwalającą na eliminację bądź ograniczenie tego zjawiska podano w pracy [2]. Autorzy niniejszej pracy jednak uznali, że do zrealizowania przyjętego celu badań należy zastosować metody analityczne które, chociaż mniej dokładne i o ograniczonym zakresie stosowania, pozwolą uzyskać stabilne wyniki obliczeń dla rozpatrywanych $\mathrm{w}$ tym opracowaniu odkształceń otworu cylindra.

\section{Matematyczny opis linii obwodowej cylindra}

Utworzenie przestrzennego obrazu otworu cylindra wymaga znajomość przebiegów jego linii obwodowych (leżących w wybranych płaszczyznach przekroju) oraz tworzących profilu. Dla wybranej płaszczyzny przekroju

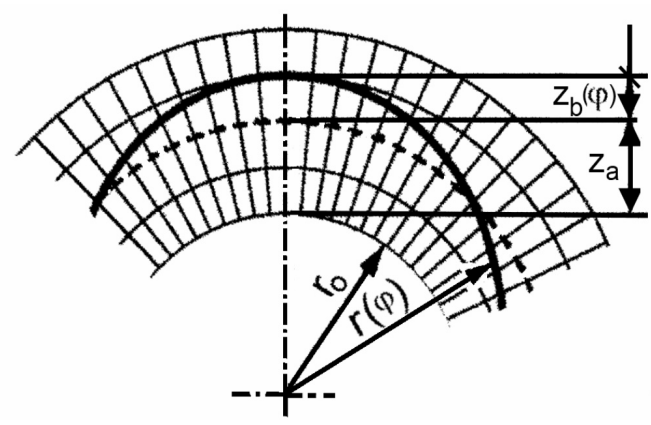

Fig. 4. The course of bore circumferential line with markings of characteristic quantities

Rys. 4. Przebieg linii obwodowej cylindra wraz z oznaczeniami charakterystycznych wielkości

zmiany promienia cylindra $\Delta \mathrm{r}(\varphi)$, spowodowany zmianą kształtu jego otworu, można wyrazić jako różnicę promieni, rzeczywistego $r(\varphi)$ i początkowego $r_{o}$, względnie jako sumę składników $z_{a}$ i z $z_{b}(\varphi)$ (rys. 4) - wzór (1),

gdzie składnik $z_{a}$ to średnia wartość przyrostu promienia cylindra, a składnik $z_{b}(\varphi)$ to odchylenie od linii średniej mierzone wzdłuż obwodu cylindra. W przypadku braku 
ring free form $v_{p}(\varphi)$ to another corresponding to the bore curvature $v_{c}(\varphi)$ (assuming the full contact between ring and bore). The basic relationship between the change in ring curvature and bending moment $\mathrm{M}_{\mathrm{g}}(\varphi)$ extorting this change has the following form

$$
v_{p}-v_{c}=-\frac{M_{g}(\varphi)}{E \cdot I}
$$

where $\mathrm{E}$ is the Young modulus while I is the inertia moment of ring cross-section.

It was proved in [7] that the bore curvature radius could be described with following formula

$$
v_{c}(\varphi)=\frac{1}{r(\varphi)}\left(1-\frac{z_{b}^{\prime \prime}(\varphi)}{r(\varphi)}\right)
$$

whereas the curvature radius of free ring neutral plane with formula

$$
v_{p}(\varphi)=\frac{1-K(1+\cos \varphi)}{r_{m}}
$$

where $\mathrm{K}$ is a ring characteristic parameter. Correlation that enables calculations of the circumferential ring pressure at the point defined by an angle was developed using Eq. (4) and (5). The way the equation was defined is described in details in [7].

$$
\begin{aligned}
& p(\varphi)=\frac{E \cdot I}{h_{p} \cdot r_{m}^{4}} . \\
& {\left[K \cdot r_{m}-\left(z_{a}+z_{b}(\varphi)+z_{b}^{\prime \prime}(\varphi)+z_{b}^{I V}(\varphi)\right)\right]}
\end{aligned}
$$

Formula (6) proves that the ring pressure varies with the change in value of circumferential line deviation from the mean line (and its $2^{\text {nd }}$ and $4^{\text {th }}$ derivative as well).

\section{Calculations of compression ring pressure against the deformed bore}

Presented example concerns a trial of computational definition of compression ring wall pressure in a bore after 7 thousand hours operation on earth moving machine.

The results of bore measurements were used for determination of an approximate course of circumferential line at the level of TDC. It was assumed that there is a symmetry of bore relative to the axis passing points 1 and 91 (see Fig. 5) in order to make the result analysis and presentation easier. Because of symmetry of results, only the part concerning the "upper" region of cylinder are presented in further charts.

According to Eq. (1) the distance between points on circumferential line and the bore axis can be described with a harmonic series

$$
r(\varphi)=r_{o}+z_{a}+\sum_{h=1}^{n} A_{h} \cos \left(h \varphi+\delta_{h}\right)
$$

deformacji cylindra (tzn. gdy $\left.\mathrm{z}_{\mathrm{b}}(\varphi)=0\right)$ składnik $\mathrm{z}_{\mathrm{a}}$ będzie wyrażał zużycie gładzi cylindra.

Do matematycznego opisu kształtu otworu cylindra można zastosować szereg harmoniczny Fouriera (2), gdzie wielkości $\mathrm{A}_{\mathrm{h}} \mathrm{i} \delta_{\mathrm{h}}$ to odpowiednio amplituda i przesunięcie fazowe kolejnych harmonicznych szeregu.

W efekcie zmian kształtu otworu cylindra nacisk znajdującego się w jego wnętrzu pierścienia również ulegnie zmianie, od początkowego stałego $\left(\mathrm{p}(\varphi)=\mathrm{p}_{\mathrm{z}}=\right.$ const $)$, do zmiennego wzdłuż obwodu cylindra. Obliczenie wartości tego nacisku wymaga wykonania opisu przebiegu linii obwodowej cylindra oraz linii obojętnej swobodnego pierścienia.

Po wprowadzeniu pierścienia do wnętrza cylindra krzywizna płaszczyzny jego warstwy obojętnej zmienia się, z odpowiadającej postaci swobodnej $v_{p}(\varphi)$ do odpowiadającej krzywiźnie cylindra $v_{c}(\varphi)$ (przy założeniu pełnego przylegania pierścienia do gładzi cylindra). Podstawowy związek pomiędzy zmianą krzywizny pierścienia i momentem gnącym $M_{\mathrm{g}}(\varphi)$ wymuszającym tę zmianę ma postać (3),

gdzie E to moduł sprężystości postaciowej, a I to moment bezwładności przekroju pierścienia.

W pracy [7] wykazano, że promień krzywizny cylindra można opisać zależnością (4), natomiast promień krzywizny warstwy obojętnej swobodnego pierścienia wzorem (5), gdzie K to parametr charakterystyczny pierścienia. Wykorzystując zależności (4) i (5) wyznaczono związek umożliwiający obliczenie wartości obwodowego nacisku pierścienia $\mathrm{p}(\varphi)$ w punkcie danym kątem $\varphi$ (sposób wyznaczenia wzoru opisano szczegółowo w pracy [7]) - wzór (6).

Z zależności (6) wynika, że nacisk pierścienia zmienia się wraz ze zmianą wartości odchylenia linii obwodowej od linii średniej $z_{b}(\varphi)$ (a także od jego 2 i 4 pochodnej).

\section{Obliczania nacisku pierścienia uszczelniającego na gładź odkształconego cylindra}

Przedstawiony dalej przykład dotyczy próby obliczeniowego wyznaczenia nacisku pierścienia uszczelniającego na gładź tulei cylindrowej, która przepracowała około 7 tys. godzin w silniku maszyny roboczej (w spychaczu). Do wyznaczenia przybliżonego przebiegu linii obwodowej na wysokości ZZ wykorzystano wyniki pomiarów otworu tulei. W celu ułatwienia analizy wyników i ich prezentacji przyjęto, że występuje symetria kształtu otworu cylindra względem osi przechodzącej przez punkty 1 i 91 - rys. 5 . Na zamieszczonych dalej wykresach, ze względu na symetrię otrzymywanych wyników, pokazywano tylko ich część dotyczącą „górnego" obszaru cylindra.

Zgodnie ze wzorem (1) odległość punktów leżących na linii obwodowej cylindra od jego osi można opisać szeregiem harmonicznym (7).

Stosując odpowiednie procedury obliczono wielkości charakteryzujące kolejne wyrazy szeregu harmonicznego. W szczególności obliczono amplitudy harmonicznych $\mathrm{A}_{\mathrm{h}}$, przesunięcia fazowe $\delta_{\mathrm{h}}$ oraz średnie zużycie $\mathrm{z}_{\mathrm{a}}$. $\mathrm{Z}$ danych zamieszczonych w tabl. 1 wynika (podano tylko wartości amplitud pierwszych 10 harmonicznych), że szczególnie 
Using the appropriate procedures the characteristic quantities of consecutive series components were calculated. In particular, harmonic amplitudes $\mathrm{A}_{\mathrm{h}}$, phase shift $\delta_{\mathrm{h}}$ and mean wear $z_{a}$ were calculated. Data presented in Table 1 (amplitude values of the first 10 harmonics were given) show that the second order harmonic reaches exceptionally high value, which proves the considerable cylinder wear as well as the 4th harmonics, which could be caused by deformations that occurred at cylinder head assembly. The amplitudes of higher order harmonics have far lower values and do not exceed the assumed accuracy of bore radius determination $(1 \mu \mathrm{m})$.

Table 1. Data used in calculation example

Tablica 1. Dane wykorzystane w przykładzie obliczeniowym

\begin{tabular}{|c|c|c|c|}
\hline $\begin{array}{c}\text { Operation time/ } \\
\text { czas pracy tulei }[\mathrm{h}]\end{array}$ & \multicolumn{3}{|c|}{7000} \\
\hline $\begin{array}{c}\text { Mean wear } \mathrm{z}_{\mathrm{a}} \\
\text { zużycie średnie } \mathrm{z}_{\mathrm{a}} \\
{[\mu \mathrm{m}]}\end{array}$ & \multicolumn{3}{|c|}{99.4} \\
\hline $\begin{array}{c}\text { Harmonic order/ } \\
\text { rzad harmonicznej }\end{array}$ & $\begin{array}{c}\text { Amplitude/ } \\
\text { amplituda Ah } \\
{[\mu \mathrm{m}]}\end{array}$ & $\begin{array}{c}\text { Harmonic } \\
\text { order/rzad } \\
\text { harmonicznej }\end{array}$ & $\begin{array}{c}\text { Amplitude/ } \\
\text { amplituda } \\
\text { Ah [ } \mu \mathrm{m}]\end{array}$ \\
\hline 1 & 2.09 & 6 & 0.76 \\
\hline 2 & 23.7 & 7 & 0.66 \\
\hline 3 & 1.10 & 8 & 0.18 \\
\hline 4 & 4.55 & 9 & 0.40 \\
\hline 5 & 0.18 & 10 & 0.37 \\
\hline
\end{tabular}

More harmonics taken into account for construction of bore circumferential line, lesser deviation of its course from the actual shape of bore (Fig. 6). The course of curves show that even the sum of ten harmonics does not reproduces accurately the shape of bore. This is due to unevenness of bore surface and relatively low precision of radius measurement. An increase of reproduction of bore shape requires more harmonics taken into consideration.

a)

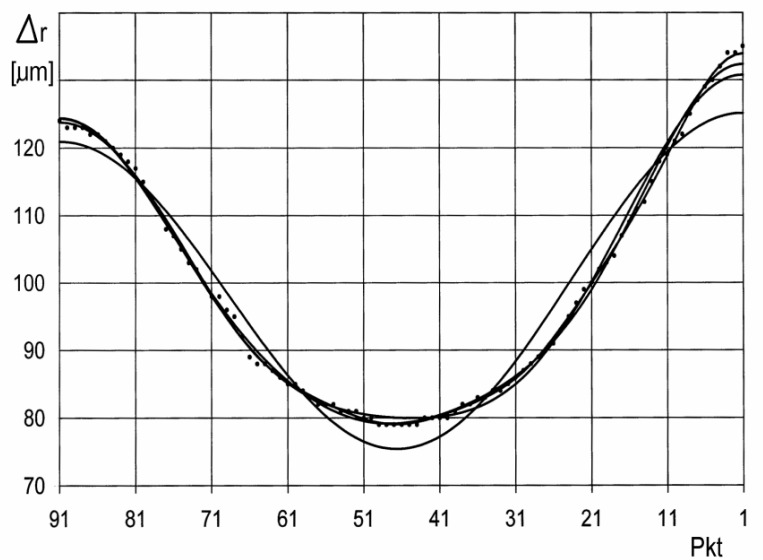

dużą wartość osiąga harmoniczna 2 rzędu, co świadczy o dużym zużyciu cylindra, a także harmoniczna 4 rzędu, co może się być spowodowane odkształceniami powstałymi podczas mocowania głowicy silnika. Amplitudy harmonicznych wyższych rzędów mają już znacznie mniejsze wartości i nie przekraczają przyjętej dokładności określania promienia cylindra $(1 \mu \mathrm{m})$.

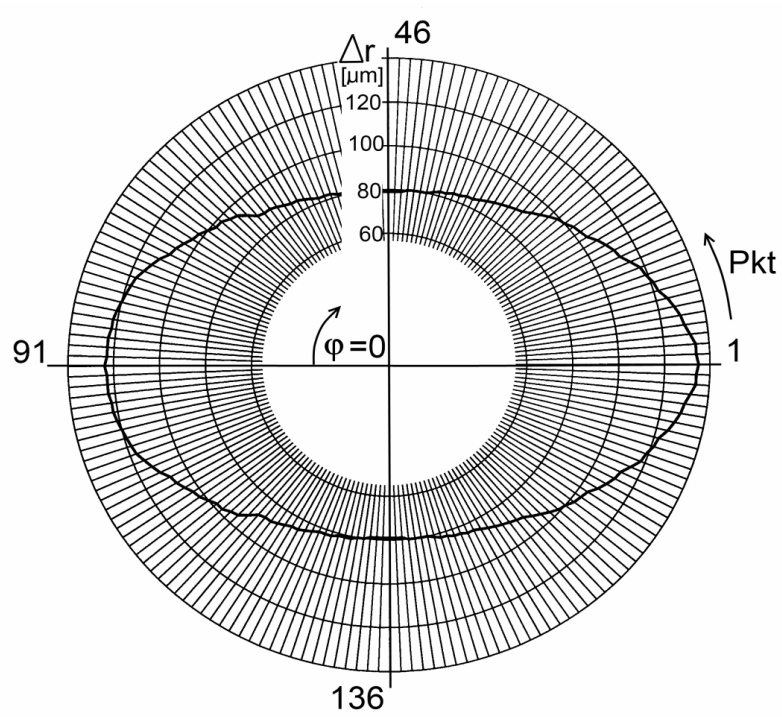

Fig. 5. The course of bore circumferential line obtained for the data undertaken for calculations

Rys. 5. Przebieg linii obwodowej cylindra uzyskany dla danych przyjętych $w$ obliczeniach

Im większa liczba harmonicznych zostanie uwzględniona przy odtwarzaniu linii obwodowej cylindra, tym mniejsze są odstępstwa jej przebiegu od rzeczywistego kształtu otworu cylindra (rys. 6). Z przebiegu krzywych wynika jednak, że nawet suma 10 harmonicznych nie pozwala na jej dokładne odtworzenie. Jest to spowodowane nierównościami na

b)

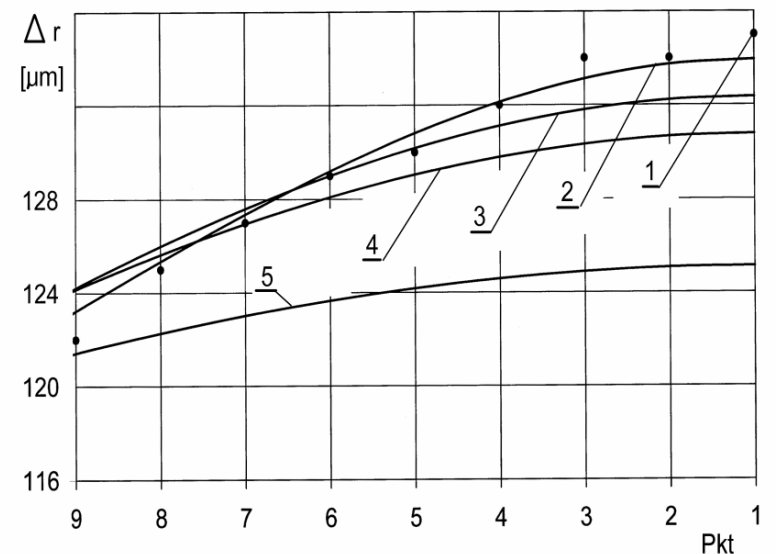

Fig. 6. Comparison of bore circumferential line course (given by the points 1) with the course of circumferential line constructed with successive harmonics of Fourier series: 2 - 10 harmonics, $3-6$ harmonics, $4-4$ harmonics, $5-2$ harmonics

Rys. 6. Porównanie przebiegu linii obwodowej cylindra (danego punktami 1) z przebiegiem linii obwodowej wyrażonej suma kolejnych harmonicznych szeregu Fouriera: 2 - 10 harmonicznych, 3 - 6 harmonicznych, 4 - 4 harmonicznych, 5 - 2 harmonicznych 
The accuracy of reproduction of actual circumferential line affects to high degree the distribution of local wall pressure values (which results from the Eq. (6)). The courses of ring pressure variations presented in Fig. 7 confirm this observation. More the bore shape differs from the regular circle, i.e. higher number of harmonics is necessary for its reproduction, higher is the circumferential variability of ring wall pressure.

a)

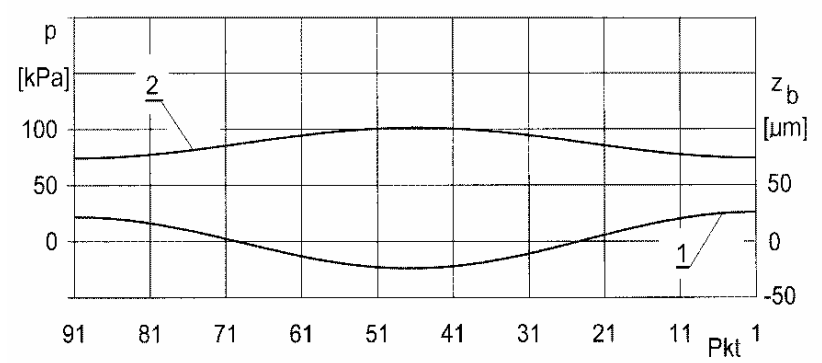

b)

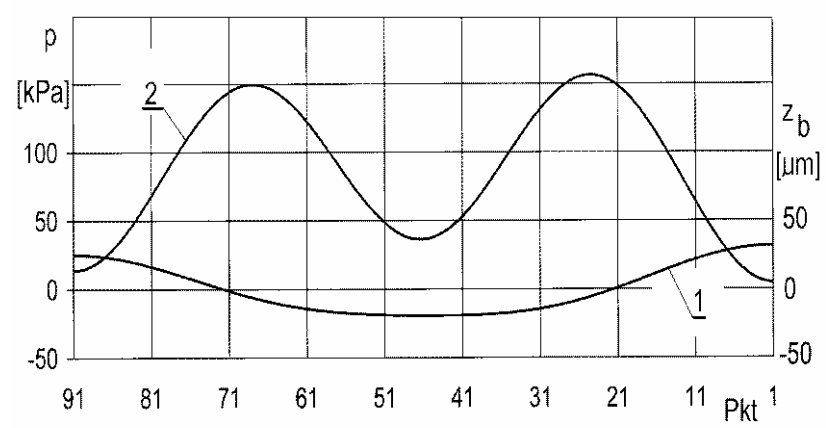

c)

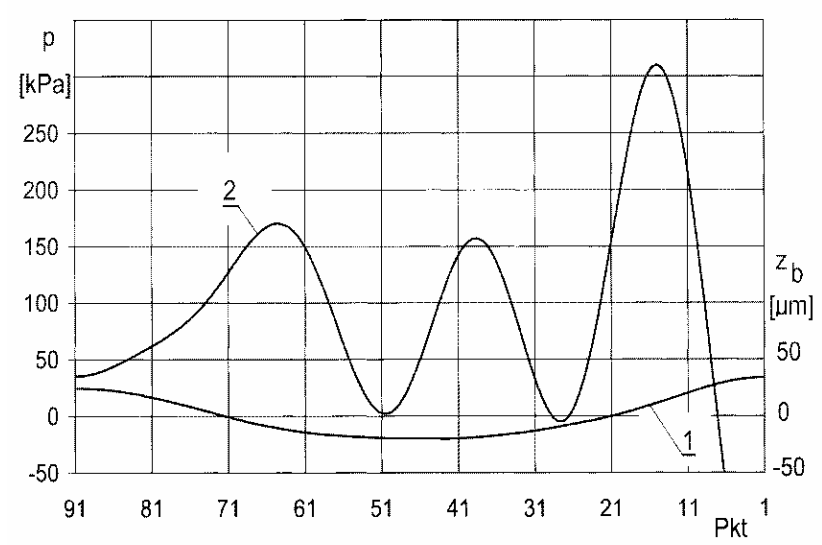

Fig. 8. Circumferential courses of ring pressure (2) and of bore circumferential line (1) given as a sum of: 2 harmonics (a), 4 harmonics (b) and 8 harmonics (c)

Rys. 8. Przebiegi obwodowe nacisku pierścienia (2) i linii obwodowej cylindra (1), danej suma: 2 harmonicznych (a) 4 harmonicznych (b) i 8 harmonicznych (c)

To follow fully this correlation the courses of circumferential line and relative ring pressure calculated as a sum powierzchni gładzi, a także względnie małą dokładnością pomiarów promienia. Zwiększenie dokładności odtworzenia przyjętego kształtu otworu cylindra wymaga uwzględnienia harmonicznych wyższych rzędów.

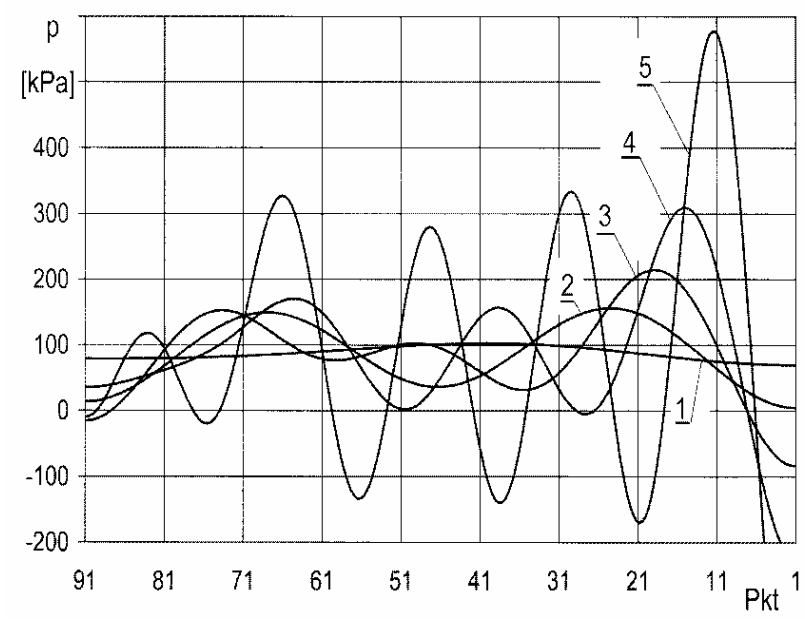

Fig. 7. Changes in ring circumferential wall pressure for bore circumferential line constructed as a sum of: 3 harmonics (1), 4 harmonics (2), 6 harmonics (3), 8 harmonics (4), 10 harmonics (5)

Rys. 7. Zmiany obwodowego nacisku pierścienia na gładź cylindra, którego linię obwodowa opisana sumą: $1-3$ harmonicznych,

2-4 harmonicznych, 3-6 harmonicznych, 4-8 harmonicznych, 5-10 harmonicznychv

Dokładność odtworzenia rzeczywistej linii obwodowej ma duży wpływ na rozkład lokalnych nacisków pierścienia na gładź cylindra (co wynika ze wzoru (6)). Potwierdzają to przebiegi zmian nacisku pierścienia zamieszczone na rys. 7. Im bardziej kształt otworu cylindra będzie różnił się od okręgu (tzn. im większą liczbę harmonicznych będzie niezbędna do odtworzenie jego kształtu), tym większa będzie obwodowa zmienność nacisku pierścienia.

W celu pełniejszego prześledzenia tej współzależności na kolejnych wykresach pokazano przebiegi linii obwodowej oraz odpowiadające jej przebiegowi naciski pierścienia, wyznaczone przy zsumowaniu odpowiednio 2, 4 i 8 harmonicznych. Przy uwzględnieniu tylko 2 harmonicznych (rys. 8a), pomimo znacznej wartości amplitudy odkształcenia otworu, wahania obwodowego nacisku pierścienia wokół wartości początkowej $\left(\mathrm{p}_{\mathrm{z}}=94\right.$ $\mathrm{kPa})$ są względnie małe. Maksymalna wartość nacisku występuje w tym punkcie linii obwodowej, dla której promień jest najmniejszy.

Przy bardziej złożonych postaciach przebiegu linii obwodowej cylindra (np. opisanej sumą 8 harmonicznych - rys. 8c) nacisk zmienia się już znacznie gwałtowniej. Pojawiają się odcinki linii obwodowej, na których jego wartość jest mniejsza od zera (co oznacza brak docisku pierścienia, a w rezultacie możliwość wystąpienia przedmuchu gazów). 
of 2, 4 and 8 harmonics are presented in following figures. Taking into account only 2 harmonics (Fig. 8a) fluctuations of circumferential ring pressure around the initial value $\left(\mathrm{p}_{\mathrm{z}}=94 \mathrm{kPa}\right)$ are relatively low despite considerable bore deformation. Maximum pressure occurs at this point of circumferential line where the radius is the shortest.

For more complicated forms of circumferential line course (as the one described with a sum of 8 harmonics see Fig. 8c) the pressure varies more intensively. Sections of circumferential line occur where this value in less than zero (which means the lack of pressure and possibility of blow-by as a result).

\section{Summary and conclusions}

Presented in this paper considerations and results of exemplary calculations carried out using a computer program developed by the authors show a close relation between the shape of cylinder bore and distribution of ring circumferential pressure. The minor deformations of bore of about a fraction of millimeter particularly highly affect the pressure variations.

However, it should be remembered that the presented tests were carried out without oil layer between ring face and bore. On a running engine the oil film separates both surfaces creating a carrying layer of a dozen or so micrometers in thickness which eliminates or at least limits the effect of micro-unevenness. It means that the effect of so minor deformations could be neglected when analyzing the distribution of compression ring wall pressure, whereas investigation should include the effect of greater deformations (described with harmonics of lower order).

Presented analyzes also omits the evaluation of the effect of bore deformations on stress that occurs during ring operation. This problem need investigating because major deformations of bore could bring about excessive stress in ring material leading to its failure.

\section{Podsumowanie i wnioski}

Przedstawione w opracowaniu rozważania oraz wyniki przykładowych obliczeń, wykonanych za pomocą opracowanego przez autorów programu komputerowego, wskazują na silne powiązanie kształtu otworu cylindra z rozkładem nacisków obwodowych pierścienia. Szczególnie duży wpływ na zmiany nacisku mają niewielkie lokalne odkształcenia gładzi, o wartości nie przekraczającej ułamka mikrometra.

Należy jednak pamiętać, że przedstawione badania przeprowadzono przy założeniu braku warstwy oleju (filmu olejowego) rozdzielającej współpracujące powierzchnie robocze pierścienia i cylindra. W pracującym silniku film olejowy, tworząc warstwę nośną o grubości od ułamka do nawet kilkunastu mikrometrów, rozdziela te powierzchnie, eliminując lub znacznie ograniczając wpływ mikronierówności. Oznacza to, że przy analizie rozkładu nacisku pierścienia uszczelniającego na gładź cylindra wpływ tych niewielkich odkształceń może zostać pominięty, natomiast badania powinny obejmować wpływ odkształceń o dużej wartości (danych harmonicznymi niższego rzędu).

W przedstawionych tu analizach pominięto także ocenę wpływu zniekształceń otworu cylindra na naprężenia powstające $\mathrm{w}$ pierścieniu podczas jego pracy. Problem ten wymaga zbadania, bowiem duże odkształcenia cylindra mogą spowodować nadmierny wzrost naprężeń w materiale pierścienia, doprowadzając do jego uszkodzenia.

\section{Bibliography/Literatura}

[1] Gruszka J.: Technologiczne kształtowanie cech funkcjonalnych warstwy powierzchniowej tulei cylindrowej. Wydawnictwo PP, Poznań 2012.

[2] Iskra A.: Studium konstrukcji i funkcjonalności pierścieni w grupie tłokowo-cylindrowej. Wydawnictwo PP, Poznań 1996.

[3] Kozaczewski W.: Konstrukcja grupy tłokowo-cylindrowej silników spalinowych. WKŁ, Warszawa 2004.

[4] Piaseczny L.: Technologia naprawy okrętowych silników spalinowych. Wydawnictwo Morskie, Gdańsk 1992.

Wojciech Serdecki, DSc., DEng. - Professor in the Faculty of Machines and Transport at Poznań University of Technology.

Dr hab. inż. Wojciech Serdecki - profesor na Wydziale Maszyn Roboczych i Transportu Politechniki Poznańskiej.

e-mail: wojciech.serdecki@put.poznan.pl
[5] Serdecki W., Krzymień P.: Distribution of piston compression ring pressure against the deformed cylinder wall. Combustion Engines, No. 2/2011.

[6] Serdecki W.: Analysis of ring pressure distribution on a deformed cylinder face. Journal of POLISH CIMAC. Energetic aspects, Gdańsk 2012, Vol. 7, No. 1.

[7] Serdecki W., Krzymień P.: How the wear of cylinder liner affects the cooperation of piston-cylinder assembly of IC engine. Journal of Kones, Warsaw 2012.
Piotr Krzymień, DEng. - doctor in the Faculty of Machines and Transport at Poznań University of Technology.

Dr inż. Piotr Krzymień-adiunkt na Wydziale Maszyn Roboczych i Transportu Politechniki Poznańskiej. e-mail:piotr.krzymien@put.poznan.pl

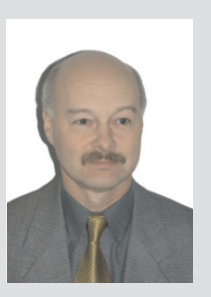

